\title{
Stock Liquidity and Auditor Choice
}

\author{
Juan Qin \\ State University of New York at Oneonta
}

This paper investigates whether firms' stock liquidity is associated with their auditor choice. Papers that support stock liquidity reinforces institutional monitoring incentives are generally based on one of two arguments: intervening in management decisions by helping investors overcome free-rider problems, or disciplining management through the threat of exit. Since stock liquidity can enhance institutional monitoring, firms with higher stock liquidity may have incentives to hire higher quality auditors to satisfy the demand of institutional investors. As predict, I find that firms with liquid stocks are more likely to appoint higher quality auditors such as Big 4 and industry specialist.

Keywords: stock liquidity, auditor choice, institutional monitoring

\section{INTRODUCTION}

This paper investigates the impact of U.S. firms' stock liquidity on auditor choice. The continued concentration in the audit market is the motivation of this study. After the failure of Arthur Andersen and the passage of the Sarbanes-Oxley Act in 2002, various federal organizations that have a role in overseeing activities in the audit market, including SEC and PCAOB have expressed concern about the high degree of concentration in the audit market and have encouraged public companies to consider using smaller accounting firms (GAO, 2008). Since the oligopoly in the audit market have potential to compromise the role of auditing, which is to provide high quality audited information to investors, and may also impede the function of SEC to protect investors. Specifically, it is possible for dominant auditors to use their market power to charge uncompetitive prices. We already saw that audit fees rose significantly in recent years. Although this increase may attribute to other factors, like auditing requirements, expanding accounting, and higher cost for personnel in accounting, it is still hard to rule out the effect of concentration in audit market. Further, audit quality is another concern. Accounting firms with significant market power may reduce the quality of their service because the lack of competitive alternatives would limit customers' ability to obtain services elsewhere. The case of Arthur and Andersen illustrates this point well, because even for most clients of Arthur and Andersen, they still switched to other Big 5 auditors after the scandal (Barton, 2005), and thus the dissolution of Arthur and Andersen further reduces client firms' auditor choices in the concentrated audit market. Academics and business groups have put forth proposals to reduce audit market concentration, however, none was widely supported, since market participants raised questions about the overall effectiveness, feasibility, and benefit of these proposals (GAO, 2008), and the concentration in audit market continues for public companies.

Since the potential adverse effects of further concentration of audit market, it is meaningful to explore the attributions to firms' auditor choice. Although this topic is extensively studied (e.g., Abbott and Parker, 
2000; Hope et al., 2008; Wang et al., 2008; Guedhami et al., 2009; Ho and Kang, 2013; Kahn et al., 2015), I explore a potential gap in the audit literature by investigating the attribution of stock liquidity to audit choice. Notwithstanding stock liquidity has remarkable influence on firms' decision making by enhancing institutional monitoring (e.g., Edmans, 2009; Edmans and Manso, 2011; Edmans et al., 2013), the topic has remained relatively under researched in accounting literature. Likewise, the influence of stock liquidity has received little attention of audit researcher. Furthermore, the current documented factors which determine auditor choice are always classified as firms' characteristics, such as corporate governance, political connection, ownership structure, organization culture and so on (e.g., Hope et al., 2008; Wang et al., 2008; Guedhami et al., 2014; Ho and Kang, 2013). This study distinguishes itself by examining whether auditor choice will be affected by stock liquidity, one aspect of capital market microstructure, which is closely related to investors.

My arguments are based on the extant literature. On one hand, it is expected that stock liquidity will mitigate the demand for audit quality, since stock liquidity can reduce the agency problem by enhancing the intensive institutional monitoring. On the other hand, the present of strong monitoring incentives may require high quality audit as a safeguard to provide reliable information to all investors. The conflicting arguments make the research on the relationship between stock liquidity and the demand of audit quality a matter of empirical interest. Following the existing literature, I use Big 4 and industry specialist as the proxies of high quality audit and use Amihud's (2002) illiquidity as the measure of stock liquidity to address the research objectives. Employing a sample consisting of U.S. firms for the period 2007-2018, I find the overall results indicating that firms with more liquid stock are inclined to demand high quality audit. The finding is consistent when additional tests are applied, including testing the effect of client firms' size on Big 4 choice, the sensitivity of the finding to the other measures of industry specialist and stock liquidity, and the impact of financial crisis on the results. Finally, although the prior tests are suggestive of a role for stock liquidity in auditor choice, they are cross-sectional results, and thus suffer from the endogeneity problem. I address the concern by conducting a two-stage least squares analysis.

This paper makes contributions in several ways. First, it closes a gap and extends stock liquidity study from financial research into accounting. Second, it contributes to the literature by suggesting that stock liquidity has a significant influence on firms' accounting properties through its impact on firms' auditor choice. Third, this study also contributes to the practice by providing a complementary explanation to the concentration in audit market from the angle of stock liquidity, and the finding will have implications to the participants who are interested in it.

The remainder of this paper proceeds as follows. The second section provides reviews of the literature and hypothesis development. The third section describes the measures used for the dependent and control variables, the research design and the sample section procedure. The fourth section presents our empirical results. The fifth section provides the conclusion.

\section{THEORETICAL FRAMEWORK AND HYPOTHESIS DEVELOPMENT}

\section{Stock Liquidity and Institutional Monitoring}

The extant literature identifies two possible mechanisms through which stock liquidity enhances institutional monitoring. The first theory in this vein includes Maug (1998), Kahn and Winton (1998), and Noe (2002), which support that stock liquidity may help to overcome the free-rider problem and strengthen the incentives of institutions to engage in costly monitoring. If a firm's stock is liquid enough, a shareholder planning an intervention can profit from informed trading and recoup the cost of intervention by buying shares at a cost that does not fully reflect the value impact of their intervention. Furthermore, trading profits are increasing in stock liquidity because liquidity makes informed trades to hide their purchases by pooling with noise traders, and therefore the probability of monitoring by large shareholders is increasing in stock liquidity. In addition, Palmiter (2002), Admati and Pfleiderer (2009) and Edmans (2009) also predict a positive impact of stock liquidity on institutional monitoring. In this model, they find when managerial compensation is tied to the stock price, the threat that informed large shareholders may sell their shares and exit improves managerial incentives to maximize shareholder wealth. Stock liquidity increases the cost of 
opportunism to managers by facilitating the informed selling which drives down the price of the targeted firms. The higher liquidity makes this threat of exit more credible, since higher stock liquidity lowers transactions costs, then even minor negative signals suffice to induce shareholders to exit.

\section{Stock Liquidity and Auditor Choice}

Stock liquidity may mitigate the need of high quality audit. According to Watts and Zimmerman (1983) and Healy and Palepu (2001), the demand for audit quality is driven by information asymmetry and conflict of interest between managers and investors. Companies with higher stock liquidity are subject to the less severe agency problem, since as we discussed, stock liquidity enhances the institutional monitoring and reduces the managerial opportunism (Palmiter, 2002; Edmans, 2009; Admati and Pfleiderer, 2009), which, in turn, improves firms' information effectiveness and financial reporting quality (Fang et al., 2009; Fang, 2012). Due to the mitigated agency problem, it is expected that firms with more liquid stock will have less demand for audit quality.

Conversely, stock liquidity can increase the demand of audit quality for two reasons. First, the benefit to recruit high quality auditors is widely documented. For instance, high quality auditors are more likely to issue modified audit opinions to firms with questionable accounting practices (DeFond et al.,1999), and facilitate the flow of more credible firm-specific information into the stock market (Gul et al., 2010), and less likely to be subject to political influences (Chan et al., 2006). Therefore, once shareholders, either as individually or as groups, have sufficient stock to be influential, they would apply sufficient force, either implicitly or explicitly, to obtain high quality auditors (Kane and Velury, 2004). Given that stock liquidity strengthening the influence of institutional monitors on firm decision-making (Palmiter, 2002; Edmans, 2009; Edmans et al., 2013; Norli, 2014), I expect that stock liquidity could either directly (the direct intervention) or indirectly (the exit threat) compel management to hire high quality auditors. Second, when managers are subject to the intense monitoring, they will have less opportunity and temptation to engage in self-stealing activities. In this case, managers prefer to improve financial reporting to persuade outside investors that they are not extracting private benefit by exhibiting greater demand for high quality audit (Watts and Zimmerman, 1983; Dyck and Zingales, 2004; Barton, 2005). Therefore, since stock liquidity has tendency to increase institutional monitoring incentive, firms with higher stock liquidity are more likely to hire higher quality auditors.

In the light of the discussion above, it seems that stock liquidity may either mitigate or enhance the demand for high quality audit. However, which force dominates the relationship between stock liquidity and auditor choice being a matter of empirical interest. Based on the controversial arguments, my hypothesis is a null hypothesis and stated as following: ceteris paribus, stock liquidity has no significant impact on firms' audit choice.

\section{RESEARCH DESIGN}

\section{Measures of Stock Liquidity}

The main stock liquidity measure used in this paper is Amihud's (2002) illiquidity (ILLIQ). Although several definitions of stock liquidity are offered in the market microstructure literature, the most prominent is Kyle's (1985) lambda (Bardos, 2011). I adopt ILLIQ which is calculated based on daily CRSP data, since $I L L I Q$ is a proxy of Kyle's lambda, measuring the price impact of trading volume using high frequency data (Bardos, 2011). Besides $I L L I Q$, the effective spread that requires intraday data from $T A Q$ database for calculation is also frequently used to measure liquidity. However, $T A Q$ data is not available for many small firms (Badertscher and Burks, 2011), which constitute a significant portion of our sample. By contrast, $C R S P$ database which is used to compute ILLIQ doesn't have the problem of data availability, and the correlation of ILLIQ with effective spread is $93.7 \%$ (Bardos, 2011), so I adopt ILLIQ as the primary measure of stock liquidity in this study. The illiquidity measure is computed as following:

$$
\text { ILLIQ }=\text { Average }\left(\left|r_{t}\right| \text { Volume }_{t}\right) * 10^{6}
$$


where $\left|r_{t}\right|$ is the absolute value of stock return on day $\mathrm{t}$, and Volume $_{t}$ is the daily dollar trading volume on day t. The average is calculated over all positive-volume days, since the ratio is undefined for zero-volume days. In addition, to account for skewness in the distribution, log-transform of this measure is calculated. Finally, since a higher value of the measure corresponds to a lower level of liquidity, I multiply it by -1 to facilitate interpretation as a measure of stock liquidity.

\section{Measures of Auditor Choice}

Audit quality is not directly observable. Several proxies are used to capture the quality association of audit services with auditor characteristic, like auditor size, industry specialization, auditor tenure, and audit fees versus non-audit fees. I use two alternative proxies for audit quality in this paper. The first proxy captures the impact of stock liquidity on recruiting high quality auditor based on auditor size: Big 4, which equals 1 for firms audited by one of Big 4 firms, and 0 otherwise. A deal of studies (for example, DeAngelo, 1981; Simunic and Stein, 1987) consider audit firm size to be an important measure of audit quality, and it is widely used in auditing research (Copley \& Douthett 2002; Wang et al.2008). The second measure is adopted to respond Hay's (2013) call for alternative proxies for audit firms' differentiation, so I use the likelihood of recruiting industry specialist auditor as another proxy of audit choice. Industry specialist variable is also a dummy variable which equals 1 if the auditor is an industry specialist, and otherwise 0 . The computation of auditor industry expertise is based on audit firms' market share in audit fees within industry groups classified by two-digit SIC codes (Hogan and Jeter 1999; Feguson et al. 2003). An audit firm is defined as an industry specialist if its market share is ranked number one at the national level (Reichelt et al. 2010; Krishnan et al. 2013).

\section{Empirical Model}

Following Fang et al. (2017), I use the following logistic model to test the role that stock liquidity plays in auditor choice:

$$
\begin{aligned}
A C N_{i t}= & a_{0}+a_{1} * I L L I Q_{i t}+a_{2} * S I Z E_{i t}+a_{3} * L E V_{i t}+a_{4} * I N V_{i t}+a_{5} * R O A_{i t}+a_{6} * G R O W T H_{i t} \\
& +a_{7} * L L O S S_{i t}+a_{8} * S E G_{i t}+a_{9} * C U R R_{i t}+a_{10} * A T U R N_{i t}+a_{11} * F O R E I G N_{i t} \\
& + \text { Industry Fixed Effect }+ \text { Year Fixed Effect }+e
\end{aligned}
$$

where $A C N$ stands for variables of auditor choice, and $N$ equals to 1 or $2 . A C 1$ represents choice between Big 4 and Non-Big 4 and AC2 represents choice between Industry Specialist and Non-Industry Specialist. Further, $A C N$ equals to 1 if auditor choice is either Big 4 or Industry Specialist, and equals to 0 if auditor choice is either Non-Big 4 or Non-Industry Specialist. Again, Since ILLIQ stands for measure of stock liquidity, consistent with the hypothesis, the coefficient of ILLIQ is uncertain, and the association between stock liquidity and auditor choice is under test.

To isolate the role of stock liquidity, Equation (1) controls a branch of variables known to affect auditor choice (e.g., Mansi et al. 2004; Fan and Wong 2005; Lennox 2005; Fortin and Pittman2007; Choi and Wong 2007; Wang et al. 2008; Guedhami et al. 2009). It includes firm size (SIZE), measuring with the natural logarithm of total sale, financial leverage ( $L E V)$, coding as the ratio of long-term debt to total equity, asset structure $(I N V)$, captured by the ratio of inventory to total assets, profitability $(R O A)$, being the return on assets ratio, growth $(G R O W T H)$, amounting to the sales growth ratio in the past year, financial loss for prior year (LLOSS), segment (SEG), measuring with the number of business segments based on two-digit SIC codes, current ratio (CURR), asset turnover (ATURN) and foreign operations (FOREIGN). The purpose of controlling size, return on assets, loss indicator, and asset turnover is to capture the impact of firm size and performance on auditor choice. I also incorporate financial leverage and current ratio to control the influence of financial solvency and liquidity risks on audit choice. In addition, growth is controlled for the importance of a firm's capital needs to its demand for high-quality audit. Finally, industry and year fixed effects are also controlled. The definitions of all variables are provided in Appendix. 


\section{EMPIRICAL RESULTS}

\section{Data and Descriptive Statistics}

The datasets for the empirical tests are from three sources. Firms' financial information is from Compustat, the required data used to compute measures of stock liquidity is from CRSP, and the relevant audit information is available in Audit Analytics. Because the financial data used to calculate the control variable segment $(S E G)$ is available since 2007 in the database that I can access, the sample period of this study is from 2007 to 2018. After excluding financial firms and utility firms, there are totally 27,976 firmyear observations with non-missing data in the sample.

Table 1 presents the descriptive statistics of variables for the full sample of firm-year observations used in Equation (1). The overall mean of $A C 1$ is 0.769 , which indicates that approximately $77 \%$ of observations hiring Big 4 to conduct audit, and the percentage of observations to hire Industry Specialist is 0.246. Therefore, the two definitions of audit choice yield different samples, which avoid bias of sample composition in the study. Moreover, the statistical value of measure of stock liquidity ILLIQ and other variables incorporated in Equation (1), including SIZE, ROA, LEV, SEG and FOREIGN, are qualitatively similar to those in the previous studies. Finally, to avoid outliers, all continuous variables are winsorized at the 1 percent and 99 percent levels.

TABLE 1 STATISTIC DESCRIPTION FOR REGRESSION VARIABLE

\begin{tabular}{lllllll}
\hline Variables & $\mathrm{N}$ & Mean & Median & S.D. & P25 & P75 \\
\hline$A C 1$ & 27,976 & 0.769 & 1.000 & 0.421 & 1.000 & 1.000 \\
AC2 & 27,976 & 0.246 & 0.000 & 0.430 & 0.000 & 0.000 \\
ILLIQ & 27,976 & 4.985 & 5.397 & 3.197 & 2.938 & 7.384 \\
SIZE & 27,976 & 6.310 & 6.426 & 2.334 & 4.862 & 7.891 \\
LEV & 27,976 & 0.229 & 0.187 & 0.259 & 0.014 & 0.352 \\
INV & 27,976 & 0.099 & 0.057 & 0.119 & 0.004 & 0.151 \\
ROA & 27,976 & -0.038 & 0.032 & 0.403 & -0.031 & 0.074 \\
GROWTH & 27,976 & 0.161 & 0.057 & 0.758 & -0.042 & 0.181 \\
LLOSS & 27,976 & 0.327 & 0.000 & 0.469 & 0.000 & 1.000 \\
SEG & 27,976 & 1.949 & 2.000 & 0.774 & 1.414 & 2.449 \\
CURR & 27,976 & 2.862 & 2.002 & 3.158 & 1.305 & 3.233 \\
ATURN & 27,976 & 0.967 & 0.787 & 0.737 & 0.464 & 1.273 \\
FOREIGN & 27,976 & 0.427 & 0.000 & 0.495 & 0.000 & 1.000 \\
\hline
\end{tabular}

The table presents descriptive statistics of variables for 27,976 firm-year observations for the sample period 20072018. Mean, median, standard deviation, first quartile and third quartile are reported. All variables are defined in Appendix.

Table 2 shows Pearson correlations among all the variables in Equation (1). The result indicates that the correlation between the two proxies of audit choice: $A C l$ and $A C 2$ is positive and significant, which is consistent with my expectation. The result in this table also reveals that $A C 1$ and $A C 2$ positively significantly correlate to $I L L I Q$, which provides the preliminary evidence to the association between stock liquidity and auditor choice. 


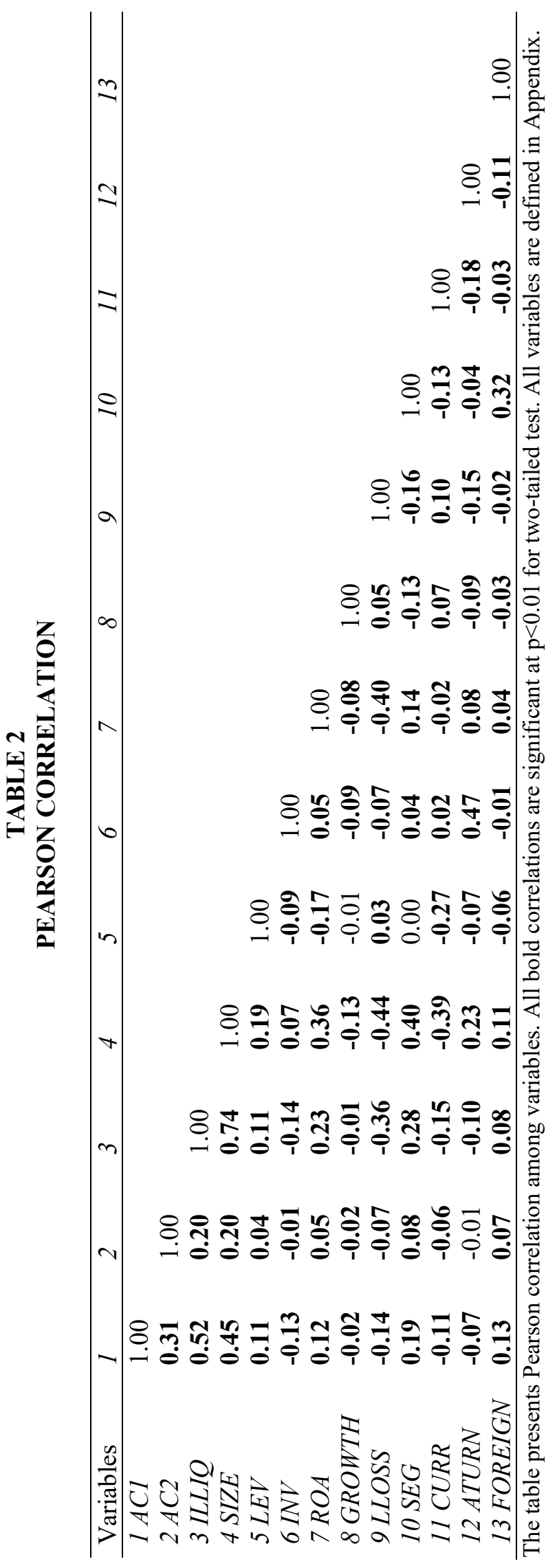




\section{Univariate Analysis}

Table 3 reports the result of univariate analysis when the full sample is partitioned by different type of auditors. The table presents the p-values from T-tests and Wilcoxon Z-tests for difference in means and medians between the two subsamples. There are Panel A, and Panel B, where use $A C 1$ and $A C 2$ to represent auditor choice, respectively. As noted in both panels, observations audited by Big 4 or Industry Specialist have characteristics that are distinguished from those audited by Non-Big 4 or Non-Industry Specialist. Specifically, the measure of stock liquidity in the observations audited by Big 4 or Industry Specialist is significantly greater than that in the observations audited by Non-Big 4 or Non-Industry Specialist. In other words, firms audited by high quality auditors are with high stock liquidity. For other characteristics, firms audited by high quality auditors have significantly larger firm size, higher financial leverage, more profitability, lower growth rate, less financial loss, more business segments and foreign operations and lower current ratio.

TABLE 3

UNIVARIATE ANALYSIS

\begin{tabular}{|c|c|c|c|c|c|c|}
\hline \multicolumn{7}{|c|}{ Panel A: The proxy of auditor choice is AC1 } \\
\hline \multirow[b]{2}{*}{ Variables } & \multicolumn{2}{|c|}{$\mathrm{AC} 1=0$} & \multicolumn{2}{|c|}{$\mathrm{ACl}=1$} & \multirow[b]{2}{*}{$\mathrm{p}$-value } & \multirow[b]{2}{*}{ Wilcoxon-p } \\
\hline & Mean & Median & Mean & Median & & \\
\hline ILLIQ & 1.974 & 1.923 & 5.889 & 6.170 & 0.000 & 0.000 \\
\hline$S I Z E$ & 4.372 & 4.496 & 6.891 & 7.007 & 0.000 & 0.000 \\
\hline$L E V$ & 0.178 & 0.087 & 0.244 & 0.212 & 0.000 & 0.000 \\
\hline$I N V$ & 0.126 & 0.081 & 0.090 & 0.052 & 0.000 & 0.000 \\
\hline$R O A$ & -0.124 & 0.012 & -0.013 & 0.036 & $\mathbf{0 . 0 0 0}$ & $\mathbf{0 . 0 0 0}$ \\
\hline GROWTH & 0.193 & 0.055 & 0.152 & 0.057 & 0.000 & 0.402 \\
\hline LLOSS & 0.451 & 0.000 & 0.290 & 0.000 & 0.000 & 0.000 \\
\hline$S E G$ & 1.681 & 1.732 & 2.029 & 2.000 & 0.000 & 0.000 \\
\hline CURR & 3.518 & 2.367 & 2.665 & 1.917 & 0.000 & 0.000 \\
\hline$A T U R N$ & 1.066 & 0.914 & 0.937 & 0.755 & 0.000 & 0.000 \\
\hline FOREIGN & 0.312 & 0.000 & 0.461 & 0.000 & 0.000 & 0.000 \\
\hline
\end{tabular}

Panel B: The proxy of auditor choice is AC2

\begin{tabular}{|c|c|c|c|c|c|c|}
\hline \multirow[b]{2}{*}{ Variables } & \multicolumn{2}{|c|}{$\mathrm{AC} 2=0$} & \multicolumn{2}{|c|}{$\mathrm{AC} 2=1$} & \multirow[b]{2}{*}{ p-Value } & \multirow[b]{2}{*}{ Wilcoxon-p } \\
\hline & Mean & Median & Mean & Median & & \\
\hline ILLIQ & 4.617 & 5.024 & 6.117 & 6.443 & 0.000 & 0.000 \\
\hline$S I Z E$ & 6.040 & 6.133 & 7.138 & 7.223 & 0.000 & 0.000 \\
\hline$L E V$ & 0.223 & 0.173 & 0.248 & 0.225 & 0.000 & 0.000 \\
\hline$I N V$ & 0.099 & 0.058 & 0.096 & 0.056 & 0.036 & 0.598 \\
\hline$R O A$ & -0.051 & 0.030 & -0.001 & 0.036 & 0.000 & 0.000 \\
\hline GROWTH & 0.172 & 0.058 & 0.128 & 0.053 & 0.000 & 0.063 \\
\hline LLOSS & 0.346 & 0.000 & 0.270 & 0.000 & 0.000 & 0.000 \\
\hline$S E G$ & 1.913 & 1.732 & 2.059 & 2.000 & 0.000 & 0.000 \\
\hline CURR & 2.977 & 2.061 & 2.509 & 1.823 & 0.000 & 0.000 \\
\hline$A T U R N$ & 0.970 & 0.791 & 0.956 & 0.775 & 0.174 & 0.120 \\
\hline FOREIGN & 0.416 & 0.000 & 0.460 & 0.000 & 0.000 & 0.000 \\
\hline
\end{tabular}

This table shows the result of univariate analysis when the sample is partitioned by different type of auditors. The bold $\mathrm{p}$-values from T-tests and Wilcoxon Z-tests for difference in means and medians are significant at $\mathrm{p}<0.001$. All variables are defined in Appendix. 


\section{Multivariate Results for Auditor Choice}

Table 4 reports the results of the test for the relationship between stock liquidity and auditor choice by running the multivariate regression model. The results for two measures of auditor choice are given in Column (1) and Column (2) respectively, and t-values are clustered by firm (Rogers 1993). In Column (1), when the proxy for auditor choice is $A C l$, the coefficient of stock liquidity (ILLIQ) is 0.042 and significant at t-value of 15.36, indicating that the higher stock liquid of a firm, the higher possibility for the firm to appoint Big 4 for audit service. In Column (2), the proxy for auditor choice is $A C 2$, and the coefficient of ILLIQ is 0.012 and significant at $\mathrm{t}$-value of 5.01, which suggests that firms with more liquid stock are more likely to hire industry specialist. For control variables in Table 4, their coefficients are consistent with their value in the extant literature. For example, larger firms, firms with higher leverage and more foreign operations, or firms exhibiting serious financial loss are more likely to engage high quality auditors.

According to the finding from the multivariate regression analysis, the established null hypothesis in this paper could be denied. The significantly positive coefficients on stock liquidity measure ILLIQ in Table 4 indicate that stock liquidity have impact on firms' decision making of auditor choice, and could increase firms' demand for high quality audit.

TABLE 4

\section{MULTIVARIATE REGRESSION RESULTS}

\begin{tabular}{llclc}
\hline & \multicolumn{3}{c}{ AC1 $(1)$} & \multicolumn{2}{c}{ AC2 (2) } \\
\hline Variables & Coef. & t-value & Coef. & t-value \\
ILLIQ & 0.042 & $15.36^{* * *}$ & 0.012 & $5.01^{* * *}$ \\
SIZE & 0.051 & $11.38^{* * *}$ & 0.030 & $6.94^{* * *}$ \\
LEV & 0.018 & 0.94 & -0.021 & -1.19 \\
INV & -0.332 & $-4.93^{* * *}$ & -0.026 & -0.42 \\
ROA & -0.020 & $-2.14^{* *}$ & -0.015 & $-1.95^{* *}$ \\
GROWTH & -0.003 & -0.75 & -0.006 & $-1.84^{*}$ \\
LLOSS & 0.064 & $7.13^{* * *}$ & 0.029 & $3.32^{* * *}$ \\
SEG & -0.002 & -0.21 & -0.001 & -0.14 \\
CURR & 0.003 & $1.78^{*}$ & 0.000 & 0.27 \\
ATURN & -0.037 & $-3.68^{* * *}$ & 0.024 & $-2.59^{* * *}$ \\
FOREIGN & 0.055 & $5.16^{* * *}$ & 0.018 & $1.67^{*}$ \\
INTERCEPT & 0.252 & $9.75^{* * *}$ & 0.010 & 0.43 \\
Industry Fixed Effects & Yes & & Yes & \\
Year Fixed Effects & Yes & & Yes & \\
No. of Observations & 27976 & & 27976 & \\
Adj. $R^{2}$ & $31.8 \%$ & & $7.1 \%$ & \\
\hline
\end{tabular}

This table presents the multivariate regression results on the effect of stock liquidity on auditor choice. The dependent variables are $A C 1$ in Column (1) and $A C 2$ in Column (2). The significance based on a two-tailed test at 10\%, 5\%, and $1 \%$ level is indicated by $*, * *$, and $* * *$ respectively. All variables are defined in Appendix.

\section{ADDITIONAL TESTS}

\section{Alternative Definitions of Stock Liquidity}

Besides Amihud's illiquidity, I adopt other two measures for stock liquidity. The first one is Turnover, which is defined as the $\log$ of the ratio of total shares traded annually divided by share outstanding. 
Jayaraman and Milbourn (2012) employ it to investigate the role of stock liquidity in the composition of CEO annual pay and the sensitivity of managerial wealth to stock price. They argue that Turnover involves scaling shares traded by shares outstanding, and implicitly controls for firm size and enables comparison across firms and over time, so it is a feasible measure of stock liquidity. The higher turnover means the higher liquidity.

The second one is Lesmond et al.'s (1999) proportion of days with zero returns. Two key arguments support this measure. First, stocks with lower liquidity are more likely to have zero-volume days and thus are more likely to have zero-return days. Second, stocks with higher transaction costs have less private information acquisition, and thus, even on positive volume days, they are more likely to have noinformation-revelation, zero return days. Lesmond et al. define the proportion of days with zero returns as

ZEROS=(\# of positive-volume days with zero return $) / T$

where $T$ is the number of trading days over the fiscal year. Since a higher value of this measure corresponds to a lower level of liquidity, I multiply it by -1 to facilitate interpretation as a measure of liquidity. The results of the analyses with these two measures of stock liquidity are showed in Table 5, which are consistent with prior results.

TABLE 5

MULTIVARIATE REGRESSION RESULTS FOR ALTERNATIVE MEASURES OF STOCK LIQUIDITY

\begin{tabular}{|c|c|c|c|c|}
\hline \multicolumn{5}{|c|}{ Panel A TURNOVER is the proxy of stock liquidity } \\
\hline \multirow[b]{2}{*}{ Variables } & \multicolumn{2}{|c|}{$\mathrm{AC} 1(1)$} & \multicolumn{2}{|c|}{$\mathrm{AC} 2(2)$} \\
\hline & Coef. & t-value & Coef. & t-value \\
\hline TURNOVER & 0.053 & $10.83 * * *$ & 0.009 & $1.91 *$ \\
\hline SIZE & 0.094 & $27.93 * * *$ & 0.043 & $13.21 * * *$ \\
\hline$L E V$ & -0.004 & -0.21 & -0.028 & -1.51 \\
\hline$I N V$ & -0.444 & $-6.51 * * *$ & -0.068 & -1.11 \\
\hline$R O A$ & -0.034 & $-3.60 * * *$ & -0.022 & $-2.61 * * *$ \\
\hline GROWTH & -0.001 & -0.22 & -0.005 & -1.59 \\
\hline LLOSS & 0.036 & $4.00 * * *$ & 0.021 & $2.47 * * *$ \\
\hline$S E G$ & -0.003 & -0.36 & -0.002 & -0.20 \\
\hline CURR & 0.007 & $3.60 * * *$ & 0.002 & 1.25 \\
\hline$A T U R N$ & -0.076 & $-7.53 * * *$ & -0.036 & $-4.13 * * *$ \\
\hline FOREIGN & 0.049 & $4.54 * * *$ & 0.016 & 1.47 \\
\hline INTERCEPT & 0.516 & $13.43 * * *$ & 0.050 & 1.36 \\
\hline Industry Fixed Effects & Yes & & Yes & \\
\hline Year Fixed Effects & Yes & & Yes & \\
\hline No. of Observations & 28161 & & 28161 & \\
\hline Adj. $R^{2}$ & $7.2 \%$ & & $6.9 \%$ & \\
\hline
\end{tabular}




\begin{tabular}{|c|c|c|c|c|}
\hline \multicolumn{5}{|c|}{ Panel B ZEROS is the proxy of stock liquidity } \\
\hline \multirow[b]{2}{*}{ Variables } & \multicolumn{2}{|c|}{$\mathrm{AC} 1(1)$} & \multicolumn{2}{|c|}{$\mathrm{AC} 2(2)$} \\
\hline & Coef. & t-value & Coef. & t-value \\
\hline ZEROS & 1.842 & $11.59 * * *$ & 0.009 & $3.56^{* * *}$ \\
\hline SIZE & 0.091 & $26.96 * * *$ & 0.043 & $12.64 * * *$ \\
\hline$L E V$ & 0.005 & 0.26 & -0.028 & -1.36 \\
\hline$I N V$ & -0.463 & $-6.83 * * *$ & -0.068 & -1.13 \\
\hline$R O A$ & -0.041 & $-4.07 * * *$ & -0.022 & $-2.67 * * *$ \\
\hline GROWTH & 0.000 & 0.06 & -0.005 & -1.63 \\
\hline LLOSS & 0.059 & $6.62 * * *$ & 0.021 & $3.07 * * *$ \\
\hline$S E G$ & -0.005 & -0.64 & -0.002 & -0.23 \\
\hline CURR & 0.007 & $3.54 * * *$ & 0.002 & 1.17 \\
\hline$A T U R N$ & -0.074 & $-7.42 * * *$ & -0.036 & $-3.99 * * *$ \\
\hline FOREIGN & 0.049 & $4.59 * * *$ & 0.016 & 1.49 \\
\hline INTERCEPT & 0.308 & $11.10 * * *$ & 0.050 & 0.91 \\
\hline Industry Fixed Effects & Yes & & Yes & \\
\hline Year Fixed Effects & Yes & & Yes & \\
\hline No. of Observations & 28165 & & 28165 & \\
\hline $\operatorname{Adj} . R^{2}$ & $30.5 \%$ & & $7.0 \%$ & \\
\hline
\end{tabular}

\section{Alternative Definitions of Industry Specialist}

Besides the proxy of Industry Specialist already been employed in the prior test, the extant studies also use other measures for industry specialization. To test the sensitivity of our findings to the definition of industry expertise, I adopt other two measures of Industry Specialist and re-run the regression. The first alternative measure is still computed based on audit firms' market share in audit fees within industry groups classified by two-digit SIC codes. Specifically, an auditor is defined as an Industry Specialist if the auditor has a market share greater than 30\% in a two-digit SIC category in a particular year (Reichelt et al. 2010; Krishnan et al. 2013). I use Specialist1 standing for it. Second, an auditor is also defined as an Industry Specialist when the auditor has the greatest number of clients in the industry (Balsam et al., 2003). I use Specialist 2 standing for it. The analyses under these two definitions yield results tabulated in Table 6, which suggest that the prior finding is robust to the different measures of Industry Specialist. 
TABLE 6

MULTIVARIATE REGRESSION RESULTS FOR ALTERNATIVE PROXIES OF AUDITOR CHOICE

\begin{tabular}{lllll}
\hline & \multicolumn{2}{c}{ Specialist1 (1) } & \multicolumn{2}{c}{ Specialist2 (2) } \\
\hline Variables & Coef. & t-value & Coef. & t-value \\
ILLIQ & 0.015 & $5.98^{* * *}$ & 0.019 & $6.30^{* * *}$ \\
SIZE & 0.029 & $6.47^{* * *}$ & 0.015 & $2.93^{* * *}$ \\
LEV & -0.016 & -0.92 & -0.035 & $-1.70^{*}$ \\
INV & -0.031 & -0.49 & -0.184 & $-2.54^{* * *}$ \\
ROA & -0.021 & $-2.20^{* *}$ & -0.018 & $-1.64^{*}$ \\
GROWTH & -0.007 & $-1.96^{* *}$ & 0.005 & 1.32 \\
LLOSS & 0.032 & $3.73^{* * *}$ & 0.037 & $3.53^{* * *}$ \\
SEG & 0.008 & 1.00 & -0.028 & $-2.82^{* * *}$ \\
CURR & 0.000 & -0.11 & 0.002 & 1.28 \\
ATURN & -0.020 & $-2.23^{* *}$ & -0.033 & $-3.02^{* * *}$ \\
FOREIGN & 0.017 & 1.54 & 0.011 & 0.85 \\
INTERCEPT & -0.012 & -0.50 & 0.196 & $7.27^{* * *}$ \\
Industry Fixed Effects & Yes & & Yes & \\
Year Fixed Effects & Yes & & Yes & \\
No. of Observations & 27976 & & 28165 & \\
Adj. R $^{2}$ & $15.4 \%$ & & $5.8 \%$ & \\
\hline
\end{tabular}

This table presents the multivariate regression results on the effect of stock liquidity on auditor choice. The dependent variables are Specialist 1 and Specialist 2 respectively. Significance based on a two-tailed test at $10 \%, 5 \%$, and $1 \%$ level is indicated by $* * *$, and $* * *$ respectively. All variables are defined in Appendix.

\section{Effect of Client Firm Size on Big4 Choice}

As reported in Table 1, around $77 \%$ of large public firms saw their auditor choice as limited to Big 4 firms. There is also research supporting that client firm size is significantly associated with the provision of services of large audit firms. To exclude the concern that the finding from the prior tests is driven by clients' firm size, a further evidence is provided. I partition the sample into quantiles by client size, and rerun the regression for each quantile. The results are presented in Table 7 and show that the association between stock liquidity and auditor choice is robust across the whole range of clients' firm size. Therefore, the prior result is not driven by clients with large firm size. 
TABLE 7

EFFECT OF CLIENT FIRM SIZE ON BIG4 CHOICE

\begin{tabular}{lllllll}
\hline & \multicolumn{2}{c}{ Q1: Small Size } & \multicolumn{2}{c}{ Q2: Median Size } & \multicolumn{2}{c}{ Q3: Large Size } \\
\hline Variables & Coef. & t-value & Coef. & t-value & Coef. & t-value \\
ILLIQ & 0.050 & $10.91^{* * *}$ & 0.024 & $4.04^{* * *}$ & 0.009 & $3.89 * * *$ \\
SIZE & 0.063 & $7.29^{* * *}$ & 0.104 & $5.89^{* * *}$ & 0.007 & $1.70^{*}$ \\
LEV & -0.019 & -0.65 & -0.001 & -0.04 & 0.021 & 1.16 \\
INV & -0.489 & $-5.39^{* * *}$ & -0.158 & -1.25 & -0.002 & -0.03 \\
ROA & -0.028 & $-2.87^{* * *}$ & -0.112 & $-2.64^{* * *}$ & 0.008 & 0.29 \\
GROWTH & -0.002 & -0.60 & -0.026 & $-2.33^{* *}$ & -0.019 & $-2.06^{* *}$ \\
LLOSS & 0.137 & $8.45^{* * *}$ & 0.023 & 1.63 & -0.013 & -1.43 \\
SEG & 0.020 & 1.12 & -0.003 & -0.27 & 0.002 & 0.41 \\
CURR & 0.003 & $1.85^{*}$ & -0.003 & -0.75 & -0.002 & -0.67 \\
ATURN & -0.094 & $-5.37^{* * *}$ & -0.077 & $-3.75^{* * *}$ & -0.010 & -1.18 \\
FOREIGN & 0.097 & $4.66^{* * *}$ & 0.019 & 1.04 & 0.008 & 1.23 \\
INTERCEPT & 0.273 & 1.29 & -0.490 & $-4.04 * * *$ & 0.892 & $21.99 * * *$ \\
Industry Fixed Effects & Yes & & Yes & & Yes & \\
Year Fixed Effects & Yes & & Yes & & Yes & \\
No. of Observations & 9329 & & 9325 & & 9322 & \\
Adj. R ${ }^{2}$ & $29.7 \%$ & & $13.2 \%$ & & $7.9 \%$ & \\
\hline
\end{tabular}

This table presents the multivariate regression result on the effect of clients' firm size on the association between stock liquidity and auditor choice. The dependent variable is $A C 1$. Significance based on a two-tailed test at $10 \%, 5 \%$, and $1 \%$ level is indicated by *,**, and *** respectively. All variables are defined in Appendix.

\section{Effect of Financial Crisis}

NÆES et al. (2011) illustrate that they saw liquidity in the stock market drying up as a precursor to the crisis in the real economy. Since the sample span in the previous analysis covers the 2008 crisis period, following Srinidhi et al. (2014), I conduct a separate analysis for the period from 2008 to 2010. The results are tabulated in Table 8, and again, the regression results with respect to auditor choice in Table 8 are consistent with the results reported earlier. 
TABLE 8

EFFECT OF FINANCIAL CRISIS

\begin{tabular}{llclc}
\hline & \multicolumn{2}{c}{ AC1 (1) } & \multicolumn{2}{c}{ AC2 (2) } \\
\hline Variables & Coef. & t-value & Coef. & t-value \\
ILLIQ & 0.042 & $11.67^{* * *}$ & 0.010 & $2.75^{* * *}$ \\
SIZE & 0.053 & $9.15^{* * *}$ & 0.031 & $4.65^{* * *}$ \\
LEV & 0.050 & $2.01^{* *}$ & -0.023 & -0.82 \\
INV & -0.341 & $-4.28^{* * *}$ & -0.027 & -0.34 \\
ROA & -0.033 & $-2.07^{* *}$ & -0.019 & $-1.74^{*}$ \\
GROWTH & -0.003 & -0.36 & -0.005 & -0.67 \\
LLOSS & 0.086 & $6.63^{* * *}$ & 0.040 & $2.92^{* * *}$ \\
SEG & -0.002 & -0.24 & 0.001 & 0.13 \\
CURR & 0.003 & 1.30 & -0.001 & -0.49 \\
ATURN & -0.038 & $-3.14^{* * *}$ & -0.011 & -0.86 \\
FOREIGN & 0.051 & $3.68^{* * *}$ & 0.006 & 0.35 \\
INTERCEPT & 0.273 & $8.25^{* * *}$ & 0.013 & 0.39 \\
Industry Fixed Effects & Yes & & Yes & \\
Year Fixed Effects & Yes & & Yes & \\
No. of Observations & 7818 & & 7818 & \\
Adj. $R^{2}$ & $31.4 \%$ & & $7.0 \%$ & \\
\hline
\end{tabular}

This table presents the multivariate regression results on the effect of financial crisis on the association between stock liquidity and auditor choice. The sample period is 2008 to 2010. The dependent variables are $A C 1$ and $A C 2$. Significance based on a two-tailed test at $10 \%, 5 \%$, and $1 \%$ level is indicated by $*, * *$, and $* * *$ respectively. All variables are defined in Appendix.

\section{Endogeneity Concern}

While the above tests have demonstrated a role for stock liquidity in auditor choice, they are crosssectional in nature, and thus the reverse causality problem due to simultaneity between stock liquidity and auditor choice could exist. In other words, liquidity may affect auditor choice, in the meantime, auditor choice could also affect stock liquidity. For example, Lang et al. (2012) find that high quality auditors are associated with high stock liquidity for which the proportion of zero-return trading days is used as proxy. Therefore, it is possible that the prior results could be an artifact of reverse causality. To exclude such possibility, I adopt a two-stage-least square regression to address endogeneity concern.

According to Fang et al. (2009), I adopt two instruments that are correlated with stock liquidity, but unlikely to be correlated with the error term. The first one is the lagged value of liquidity (LagLiq), and another is the median of stock liquidity for firms in the industry (IndLiq). For the median of industry stock liquidity, Fang et al. (2009) point out that the portion of a firm's liquidity that is correlated with its industry's liquidity is less likely to be correlated with unobservable factors that affect the outcome variable, which is firms' auditor choice in this study. In addition, the use of lagged liquidity as an exogenous variable helps moderate concerns that an unobservable factor in fiscal year $t$ is correlated with stock liquidity and auditor choice at time $t$.

Table 9 presents the results from the two-stage-least square regression analysis. The coefficients on LagLiq and IndLiq in the first stage regression are positive and significant, which indicate that the instruments are highly correlated with stock liquidity. The last two columns present the results of the second stage regression by regressing proxies of auditor choice on the predicted component of liquidity (PrLiq), which is the predicted value from first stage regression. Consistent with the earlier results, the coefficients 
on PrLiq are positive and significant. Therefore, the association between auditor choice and stock liquidity is robust after controlling endogeneity using a two-stage least squares specification.

TABLE 9

TWO-STAGE-LEAST SQUARES REGRESSION

\begin{tabular}{|c|c|c|c|c|c|c|}
\hline & 1 stage & & 2 stage & & & \\
\hline & ILLIQ (1) & & $\mathrm{AC} 1(2$ & & & $2(3)$ \\
\hline Variables & Coef. & t-value & Coef. & t-value & Coef. & t-value \\
\hline PrLiq & & & 0.044 & $14.22 * * *$ & 0.012 & $4.03 * * *$ \\
\hline LagLiq & 0.851 & $51.98 * * *$ & & & & \\
\hline IndLiq & 0.357 & $41.97 * * *$ & & & & \\
\hline SIZE & 0.168 & $18.50 * * *$ & 0.046 & $9.25 * * *$ & 0.030 & $6.06^{* * *}$ \\
\hline$L E V$ & -0.189 & $-4.36 * * *$ & 0.025 & 1.27 & -0.027 & -1.46 \\
\hline$I N V$ & -0.764 & $-9.47 * * *$ & -0.335 & $-4.82 * * *$ & -0.019 & -0.29 \\
\hline$R O A$ & 0.050 & 1.37 & -0.016 & -1.46 & -0.018 & $-2.14 * *$ \\
\hline GROWTH & 0.141 & $11.89 * * *$ & -0.004 & -1.03 & -0.006 & -1.62 \\
\hline LLOSS & -0.376 & $-22.37 * * *$ & 0.059 & $6.29 * * *$ & 0.026 & $2.94 * * *$ \\
\hline$S E G$ & -0.029 & $-3.24 * * *$ & -0.002 & -0.28 & -0.002 & -0.18 \\
\hline CURR & 0.017 & $5.55 * * *$ & 0.002 & 0.95 & -0.001 & -0.55 \\
\hline ATURN & -0.176 & $-12.95 * * *$ & -0.030 & $-2.80 * * *$ & -0.022 & $-2.24 * *$ \\
\hline FOREIGN & -0.054 & $-4.35 * * *$ & 0.055 & $5.00 * * *$ & 0.019 & $1.66^{*}$ \\
\hline INTERCEPT & -1.720 & $-29.49 * * *$ & 0.268 & $9.77 * * *$ & 0.016 & 0.66 \\
\hline Industry Fixed Effects & Yes & & Yes & & Yes & \\
\hline Year Fixed Effects & Yes & & Yes & & Yes & \\
\hline No. of Observations & 28307 & & 25844 & & 25844 & \\
\hline Adj. $R^{2}$ & $92.6 \%$ & & $31.7 \%$ & & $7.1 \%$ & \\
\hline
\end{tabular}

This table presents the two-stage least squares regression results on the effect of stock liquidity on auditor choice. In the first stage regression, the dependent variable is $I L L I Q$. In the second stage regression, the dependent variables are $A C 1$ and $A C 2$. Significance based on a two-tailed test at $10 \%, 5 \%$, and $1 \%$ level is indicated by *, **, and *** respectively. All variables are defined in Appendix.

\section{CONCLUSION}

Since the potential adverse effects, it is imperative for all participants, including auditors, investors and regulators to consider how to ease the continued concentration of the audit market. As an Accounting researcher, I make a complementary contribution by examining the association between stock liquidity and firms' auditor choice with the expectation to provide some references. Controlling a set of control variables and industry and year fixed effects, I find that firms with liquid stock are more likely to appoint Big 4 or Industry Specialist to provide high quality audit. To further support this claim, I conduct a series of additional tests and find consistent results. For example, I use alternative measures of auditor choice and stock liquidity respectively to examine the sensitivity of prior results, use the separate sample to test the robustness of result during the period of financial crisis, and use a two-stage least squares specification to mitigate concerns regarding endogeneity. The finding is consistent with the preceding argument that once stock liquidity facilitates the formation of stockholders that have enough influence to monitor the behavior of management, those stockholders will demand high quality audit. 
However, such demand will further exacerbate the problem of concentration in audit market. Since comparing to other accounting firms, Big 4 or industry specialist have significant advantage in terms of capacity and technical expertise which are something shareholders looking for in an auditor. For instance, for industries having specialized contracts and accounting technologies, auditor industry specialization (as evidenced by significant clienteles) will lead to a higher level of audit assurance compared to audits performed in those industries by nonspecialist auditors (Craswell et al. 1995). Results from studies also suggest that industry expertise enhances auditor judgments regarding error detection, risk assessments and audit planning (Solomon et al. 1999; Owhoso et al. 2002, Low 2004; Hammersley 2006). Therefore, other accounting firms face substantive challenges in audit market. To help them expand their market share, thus potentially easing concentration, the organizations overseeing activities in the audit market should take various measures to improve their capability and competitiveness fundamentally.

\section{REFERENCES}

Abbott, L.J., \& Parker, S. (2000). Auditor selection and committee characteristics. Auditing: A Journal of Practice and Theory, 19(2), 47-66.

Admati, A.R., \& Pfleiderer, P. (2009). The "Wall Street walk" and shareholder activism: Exit as a form of voice. Review of Financial Studies, 22(7), 2645-2685.

Amihud, Y. (2002). Illiquidity and stock returns: Cross-section and time-series effects. Journal of Financial Markets, 5(1), 31-56.

Badertscher, B.A., \& Burks, J.J. (2011). Accounting restatements and the timeliness of disclosures. Accounting Horizons, 25(4), 609-629.

Balsam, S., Krishnan J., \& Yang, J.S. (2003). Auditor industry specialization and earnings quality. Auditing: A Journal of Practice \& Theory, 22(2), 71-97.

Bardos, K.S. (2011). Quality of financial information and liquidity. Review of Financial Economics, 20(2), 49-62.

Barton, J. (2005). Who cares about auditor reputation? Contemporary Accounting Research, 22(3), 549586.

Chan, K.H., Lin, K.Z., \& Mo, P.L.L. (2006). A political-economic analysis of auditor reporting and auditor switch. Review of Accounting Studies, 11(1), 21-48.

Choi, J.H., \& Wong, T.J. (2007). Auditors governance functions and legal environments: An international investigation. Contemporary Accounting Research, 24(1), 21-46.

Copley, P.A., \& Douthett, E.B. (2002). The association between auditor choice, ownership retained, and earnings disclosure by firms making initial public offerings. Contemporary Accounting Research, 19(1), 49-75.

Craswell, A.T., Francis, J.R., \& Taylor, S.L. (1995). Auditor brand name reputations and industry specialization. Journal of Accounting and Economics, 20(3), 297-322.

DeAngelo, L. (1981). Auditor size and audit quality. Journal of Accounting and Economics, 3(3), 183199.

DeFond, M.L., Wong, T.J., \& Li, S. (1999). The impact of improved auditor independence on audit market concentration in China. Journal of Accounting and Economics, 28(3), 269-305.

Dyck, A., \& Zingales, L. (2004). Private benefits of control: An international comparison. Journal of Finance, 59(2), 537-600.

Edmans, A. (2009). Blockholder trading, market efficiency, and managerial myopia. The Journal of Finance, 64(6), 2481-2513.

Edmans, A., \& Manso, G. (2011). Governance through trading and intervention: A theory of multiple blockholders. Review of Financial Studies, 24(7), 2395-2428.

Edmans, A., Fang, V.W., \& Zur, E. (2013). The effect of liquidity on governance. Review of Financial Studies, 26(6), 1443-1482.

Fan, J.P.H., \& Wong, T.J. (2005). Do external auditors perform a corporate governance role in emerging markets? Evidence from East Asia. Journal of Accounting Research, 43(1), 35-72. 
Fang, J. (2012). Stock liquidity, price informativeness, and accrual-based earnings management. Working paper, Louisiana State University.

Fang, J., Pittman J.A., Zhang, Y., \& Zhao, Y. (2017). Auditor choice and its implications for groupaffiliated firms. Contemporary Accounting Research, 34(1), 39-82.

Fang, V., Noe, T., \& Tice, S. (2009). Stock market liquidity and firm value. Journal of Financial Economics, 94(1), 150-169.

Fortin, S., \& Pittman, J.A. (2007). The role of auditor choice in debt pricing in private firms. Contemporary Accounting Research, 24(3), 859-896.

GAO. (2008). Audits of public companies Continued concentration in audit market for large public companies does not call for immediate action. Retrieved from https://www.gao.gov/assets/280/270953.pdf

Guedhami, O., Pittman, J.A., \& Saffar, W. (2009). Auditor choice in privatized firms: Empirical evidence on the role of state and foreign owners. Journal of Accounting and Economics, 4(2-3), 151-171.

Guedhami, O., Pittman, J.A., \& Saffar, W. (2014). Auditor Choice in Politically Connected Firms. Journal of Accounting Research, 52(1), 107-162.

Gul, F.A., Kim, J.B., \& Qiu, A.A. (2010). Ownership concentration, foreign shareholding, audit quality, and stock price synchronicity: Evidence from China. Journal of Financial Economics, 95(3), $425-442$.

Hammersley, J.S. (2006). Pattern identification and industry-specialist auditors. The Accounting Review, 81(2), 309-336.

Hay, D. (2013). Further evidence from meta-analysis of audit fee research. International Journal of Auditing, 17(2), 162-176.

Healy, M.P., \& Palepu, K.G. (2001). Information asymmetry, corporate disclosure, and the capital markets: A review of the empirical disclosure literature. Journal of Financial Economics, 31(13), 405-440.

Ho, J., \& Kang, F. (2013). Auditor choice and audit fees in family firms: Evidence from the S\&P 1500. Auditing: A Journal of Practice \& Theory, 32(4), 71-93.

Hogan, C.E., \& Jeter, D.C. (1999). Industry Specialization by Auditors. Auditing: A Journal of Practice and Theory, $18(1), 1-17$.

Hope, O.K., Kang, T., Thomas, W., \& Yoo, Y.K. (2008). Culture and auditor choice: A test of the secrecy hypothesis. Journal of Accounting Public Policy, 27(5), 357-373.

Jayaraman, S., \& Milbourn, T. (2012). The role of stock liquidity in executive compensation. The Accounting Review, 87(2), 537-563.

Kahn, C., \& Winton, A. (1998). Ownership structure, speculation, and shareholder intervention. The Journal of Finance, 53(1), 99-129.

Khan, A., Muttakin, M.B., \& Siddiqui, J. (2015). Audit fees, auditor choice and stakeholder influence: Evidence from a family-firm dominated economy. The British Accounting Review, 47(3), 304 320.

Krishnan, J., Li, C., \& Wang, Q. (2013). Auditor industry expertise and cost of equity. Accounting Horizons, 27(4), 667-691.

Kyle, A. (1985). Continuous auctions and insider trading. Econometrica, 53(6), 1315-1335.

Lang, M., Lins, K.V., \& Maffett, M. (2012). Transparency, liquidity, and valuation: International evidence on when transparency matters most. Journal of Accounting Research, 50(3), 729-774.

Lennox, C.S. (2005). Management ownership and audit firm size. Contemporary Accounting Research, 22(1), 205-27.

Lesmond, D., Ogden, J., \& Trzcinka, C. (1999). A new estimate of transaction costs. Review of Financial Studies, 12(5), 1113-1141.

Low, K.Y. (2004). The effects of industry specialization on audit risk assessments and audit-planning decisions. The Accounting Review, 79(1), 201-219.

Mansi, S.A., Maxwell, W., \& Miller, D.P. (2004). Does auditor quality and tenure matter to investors? Evidence from the bond market. Journal of Accounting Research, 42(4), 755-793.

154 Journal of Applied Business and Economics Vol. 23(4) 2021 
Maug, E. (1998). Large shareholders as monitors: Is there a trade-off between liquidity and control? The Journal of Finance, 53(1), 65-98.

Noe, T.H. (2002). Investor Activism and Financial Market Structure. Review of Financial Studies, 15(1), 289-318.

Norli, Ø., Ostergaard, C., \& Schindele, I. (2014). Liquidity and shareholder activism. Review of Financial Studies, 13(2), 257-300.

Owhoso, V.E., Messier, W.F., \& Lynch, J.G. (2002). Error detection by industry specialized teams during sequential audit review. Journal of Accounting Research, 40(3), 883-900.

Palmiter, A.R. (2002). Mutual fund voting of portfolio shares: Why not disclose? Cardozo Law Review, 23(4), 1419-1491.

Pittman, J.P., \& Fortin, S. (2004). Auditor choice and the cost of debt capital for newly public firms. Journal of Accounting and Economics, 37(1), 113-136.

Reichelt, R.J., \& Wang, D. (2010). National and office-specific measures of auditor industry expertise and effects on audit quality. Journal of Accounting Research, 48(3), 647-686.

Rogers, W.H. (1993). Regression standard errors in clustered samples. STATA Technical Bulletin, 3(13), $19-23$.

Solomon, I., Shields, M.D., \& Whittington, O.R. (1999). What do industry-specialist auditors know? Journal of Accounting Research, 37(1), 191-208.

Srinidhi, B.N., Shaohua, H., \& Michael, F. (2014). The effect of governance on specialist auditor choice and audit fees in U.S. family firms. The Accounting Review, 89(6), 2297-2329.

Wang, Q., Wong, T.J., \& Xia, L. (2008). State ownership, institutional environment, and auditor choice: Evidence from China. Journal of Accounting and Economics, 46(1), 112-134.

Watts, R.L., \& Zimmerman, J.L. (1983). Agency problems, auditing, and the theory of the firm: Some evidence. Journal of Law and Economics, 26(3), 613-633.

\section{APPENDIX: VARIABLE DEFINITIONS}

\begin{tabular}{|c|c|}
\hline Variables & Description \\
\hline TURNOVER & Nature logarithm of the ratio of total shares traded annually divided by share outstanding \\
\hline ILLIQ & Average of the ratio of stock return on day $t$ divided by dollar volume on day $t$ \\
\hline ZEROS & $\begin{array}{l}\text { The percentage of zero daily returns as the number of trading days, with zero daily returns } \\
\text { and positive trading volume divided by the number of trading days over the firm's fiscal } \\
\text { year }\end{array}$ \\
\hline SIZE & Nature logarithm of Total sales (Compustat data item: SALE) at the end of the fiscal year \\
\hline LEV & $\begin{array}{l}\text { Book value of total debt (DLTT }+ \text { DLC) divided by the total assets (AT)at the end of the } \\
\text { fiscal year }\end{array}$ \\
\hline INV & The ratio of inventory to total assets \\
\hline ROA & $\begin{array}{l}\text { Firm's return-on-assets ratio calculated as net income (Compustat data item NI) divided } \\
\text { by total assets (Compustat data item AT) }\end{array}$ \\
\hline GROWTH & The sales growth ratio in the past year \\
\hline LLOSS & 1 if the firm reports a negative income, and zero otherwise \\
\hline SEG & Square root of the number of segments disclosed (Compustat Segment disclosure) \\
\hline CURR & Current asset divided by current liabilities \\
\hline ATURN & Net sales divided by total assets \\
\hline FOREIGN & $\begin{array}{l}\text { Dummy variable equal to } 1 \text { if the firm has foreign operations (Compustat data item FCA), } \\
\text { and } 0 \text { otherwise; }\end{array}$ \\
\hline $\mathrm{AC} 1$ & 1 if the firm audited by BIG4, and o otherwise \\
\hline $\mathrm{AC} 2$ & 1 if the firm audited by Industry Specialist, and 0 otherwise \\
\hline BIG4 & $\begin{array}{l}1 \text { if the firm is audited by Deloitte, Ernst \& Young, KPMG, or PricewaterhouseCoopers, } \\
\text { and } 0 \text { otherwise }\end{array}$ \\
\hline
\end{tabular}

